Review

\title{
Frontline Management of Epithelial Ovarian Cancer-Combining Clinical Expertise with Community Practice Collaboration and Cutting-Edge Research
}

\author{
Edward Wenge Wang ${ }^{1, *}$, Christina Hsiao Wei ${ }^{2}$, Sariah Liu ${ }^{1}$, Stephen Jae-Jin Lee ${ }^{3}$, \\ Susan Shehayeb ${ }^{4}$, Scott Glaser ${ }^{5}$, Richard Li ${ }^{5}$, Siamak Saadat ${ }^{1}$, James Shen ${ }^{1}$, Thanh Dellinger ${ }^{3}$, \\ Ernest Soyoung Han ${ }^{3}$, Daphne Stewart ${ }^{1}$, Sharon Wilczynski ${ }^{2}$, Mihaela Cristea ${ }^{1}$ and \\ Lorna Rodriguez-Rodriguez ${ }^{3}$ \\ 1 Department of Medical Oncology and Therapeutics Research, City of Hope National Medical Center, \\ Duarte, CA 91010, USA; sarliu@coh.org (S.L.); ssaadat@coh.org (S.S.); jashen@coh.org (J.S.); \\ dapstewart@coh.org (D.S.); MCristea@coh.org (M.C.) \\ 2 Department of Pathology, City of Hope National Medical Center, Duarte, CA 91010, USA; \\ cwei@coh.org (C.H.W.); swilczyn@coh.org (S.W.) \\ 3 Department of Surgical Oncology, City of Hope National Medical Center, Duarte, CA 91010, USA; \\ stelee@coh.org (S.J.-J.L.); tdellinger@coh.org (T.D.); ehan@coh.org (E.S.H.); lorrodriguez@coh.org (L.R.-R.) \\ 4 Department of Population Sciences, City of Hope National Medical Center, Duarte, CA 91010, USA; \\ sshehayeb@coh.org \\ 5 Department of Radiation Oncology, City of Hope National Medical Center, Duarte, CA 91010, USA; \\ sglaser@coh.org (S.G.); rli@coh.org (R.L.) \\ * Correspondence: edwang@coh.org; Fax: +1-626-301-8233
}

Received: 21 July 2020; Accepted: 28 August 2020; Published: 1 September 2020

\begin{abstract}
Epithelial ovarian cancer (EOC) is the most common histology of ovarian cancer defined as epithelial cancer derived from the ovaries, fallopian tubes, or primary peritoneum. It is the fifth most common cause of cancer-related death in women in the United States. Because of a lack of effective screening and non-specific symptoms, EOC is typically diagnosed at an advanced stage (FIGO stage III or IV) and approximately one third of patients have malignant ascites at initial presentation. The treatment of ovarian cancer consists of a combination of cytoreductive surgery and systemic chemotherapy. Despite the advances with new cytotoxic and targeted therapies, the five-year survival rate for all-stage EOC in the United States is $48.6 \%$. Delivery of up-to-date guideline care and multidisciplinary team efforts are important drivers of overall survival. In this paper, we review our frontline management of EOC that relies on a multi-disciplinary approach drawing on clinical expertise and collaboration combined with community practice and cutting edge clinical and translational research. By optimizing partnerships through team medicine and clinical research, we combine our cancer center clinical expertise, community practice partnership, and clinical and translational research to understand the biology of this deadly disease, advance therapy and connect our patients with the optimal treatment that offers the best possible outcomes.
\end{abstract}

Keywords: epithelial ovarian cancer; frontline treatment; surgical debulking; adjuvant chemotherapy; maintenance therapy; PARP inhibitor; genetics counseling; clinical research; team medicine

\section{Introduction}

Epithelial ovarian cancer (EOC) is the most common histology of ovarian cancer, defined as epithelial cancer derived from the ovaries, fallopian tubes, or primary peritoneum [1]. It is the fifth most 
common cause of cancer-related death in women in the United States, with an estimated 21,750 new cases and 13,940 deaths in 2020 [2]. Because of a lack of effective screening [3] and non-specific symptoms, EOC is typically diagnosed at an advanced stage (FIGO stage III or IV) and approximately one third of patients have malignant ascites at initial presentation. The treatment of ovarian cancer is primarily limited to cytoreductive surgery and systemic chemotherapy. Despite the advances with new cytotoxic and targeted therapies, the five-year survival rate for all-stage EOC in the United States is $48.6 \%$ [4]. The delivery of up-to-date guideline care and multidisciplinary team efforts are important drivers of overall survival [5].

The City of Hope National Medical Center $(\mathrm{COH})$ is an NCI-designated Comprehensive Cancer Center based in Duarte, California. Its service area includes Los Angeles, San Bernadino, Riverside, and Orange Counties. Together, these four counties are home to $46 \%$ of California's total population. $\mathrm{COH}$ delivers high quality cancer care to this sizable demographic through its large network of community oncology practice clinics in the area. In this paper, we review the frontline management of EOC and how we combine our cancer center clinical expertise, community practice partnership, and clinical and translational research to understand the biology of this deadly disease and advance therapy.

\section{Surgical Management}

Cytoreductive surgery (debulking) plays a fundamental role in managing EOC. Studies show that survival is inversely correlated with the volume of residual disease after cytoreductive surgery [6-13]. Thus, the goal of surgery is to remove all visible disease $[6,9,12,14-18]$. In a 2011 meta-analysis of 11 retrospective studies of primary cytoreduction for advanced EOC, there was improved survival with optimal (residual disease $\leq 1 \mathrm{~cm}$ in maximum tumor diameter) versus suboptimal (residual disease $>1 \mathrm{~cm}$ in maximum tumor diameter) cytoreduction (hazard ratio (HR) 1.36, 95\% CI 1.10-1.68), and further improved survival with no gross residual disease (HR 2.20, 95\% CI 1.90-2.54) [19]. In a 2013 meta-analysis of 18 studies (retrospective and prospective) of women with stage IIB or higher EOC who underwent cytoreduction and platinum/taxane chemotherapy, each $10 \%$ increase in the proportion of patients undergoing complete cytoreduction was associated with a 2.3 month increase in median survival compared with a 1.8 month increase for optimal cytoreduction [14].

Furthermore, improved outcomes in advanced EOC have been shown in high volume hospitals ( $\geq 20$ cases/year) and high-volume surgeons ( $\geq 10$ cases/year) [20]. Given the importance of the extent of cytoreduction and volume of cases on outcome and the potential morbidity with an extensive major abdominal surgery, predicting which patients will be able to have at least an optimal cytoreduction is valuable. This is primarily performed through physical examination and computed tomography (CT) of the chest, abdomen, and pelvis. Diagnostic laparoscopy can also be utilized to help triage patients with primary debulking or neoadjuvant chemotherapy [21-23]. It is of utmost importance that a gynecologic oncologist experienced in extensive cytoreductive surgeries evaluates the patient to determine resectability, as achieving no gross residual disease or optimal cytoreduction largely depends on the judgment, experience, skill, and aggressiveness of the surgeon. Additionally, patient factors, such as age, performance status, medical comorbidities, and preoperative nutritional status, are important considerations, as some patients may not be able to tolerate an extensive cytoreduction. The commonly accepted criteria for unresectability include mesenteric root involvement, diffuse involvement of the stomach and/or large parts of the small or large bowel, extra-abdominal disease, infiltration of the duodenum and/or parts of the pancreas (not limited to the pancreatic tail), or involvement of the large vessels of the hepatoduodenal ligament, celiac trunk, or behind the porta hepatis [24].

Our strong partnership with community practices provides a large number of patients in Los Angeles and the Greater Los Angeles area with access to a high volume, high complexity cancer center. In addition to hysterectomy, bilateral salpingo-oophorectomy, and omentectomy, additional procedures can include small bowel resection, large bowel resection, stoma formation, diaphragm peritonectomy plus/minus segmental full-thickness diaphragm resection, splenectomy plus/minus 
distal pancreatectomy, segmental liver resection, cholecystectomy, partial stomach resection, and partial bladder/ureteral resection. We advocate against routine lymphadenectomy (pelvic, para-aortic) in patients undergoing cytoreduction for stage III or IV disease as it has not been shown to improve overall survival and results in increased postoperative morbidity [25]. However, we do resect suspicious or enlarged lymph nodes to achieve a complete or optimal cytoreduction. An intraperitoneal (IP) catheter for IP delivery of adjuvant chemotherapy may be placed in select patients who have obtained optimal primary cytoreduction, as combination treatment with intravenous (IV) and IP chemotherapy has been shown to prolong overall survival [26-28]; although newer trials have advocated for IV delivery of chemotherapeutics that may have similar outcomes but less morbidity than IP chemotherapy [29].

Patients referred to $\mathrm{COH}$ from our community clinics for the surgical management of EOC are assessed by our gynecologic surgical oncologist team and we perform primary cytoreduction for EOC in selected patients (those medically fit to undergo an extensive surgery and in whom it is deemed a resection to no gross residual disease or at least in whom an optimal debulking can be achieved) followed by adjuvant chemotherapy. Other patients deemed unresectable may undergo neoadjuvant chemotherapy and then re-evaluation for possible interval cytoreduction. We perform heated intraperitoneal chemotherapy (HIPEC) in a clinical trial setting for translational purpose toward personalized medicine. We collect biospecimens including peritoneal samples with and without tumor cells, blood samples before and after HIPEC. Paired tumor/normal whole exome sequencing (WES) and whole transcriptome sequencing (RNAseq) is performed for analyses of germline and somatic genomic landscapes, as well as gene expression phenotypes before and after treatment, including the assessment of driver mutations, mutation signatures, tumor mutation burden, and immune signatures. Hyperthermia increases the penetration of chemotherapy and increases the chemosensitivity of the cancer by impairing DNA repair. Additionally, hyperthermia induces apoptosis and activates heat-shock proteins that serve as receptors for natural killer cells, inhibits angiogenesis, and has a direct cytotoxic effect by promoting the denaturation of proteins. In a 2018 randomized trial, van Driel et al. reported a nearly 12-month survival benefit in those receiving HIPEC versus no HIPEC after undergoing at least an optimal interval cytoreduction with a similar rate of grade 3 or 4 adverse events between the two groups [30]. It is unclear if the IP administration, the heat, or the additional dose of chemotherapy is responsible for the benefit as all three interventions were utilized. These results are encouraging; however, further studies are needed before there is widespread adoption of this technique, which requires additional technical expertise [31,32].

Pressurized intraperitoneal aerosol chemotherapy (PIPAC) is another approach we are evaluating in the clinical trial setting. PIPAC is a novel minimally-invasive drug delivery system in which normothermic chemotherapy is administered into the abdominal cavity as an aerosol under pressure [33,34]. This approach uses the advantage of the physical properties of gas and pressure by generating an artificial pressure gradient and enhancing tissue uptake of the aerosolized chemotherapy. Due to high local bioavailability during PIPAC, lower concentrations of chemotherapy can be utilized, thus minimizing side effects and toxicity.

\section{Gynecologic Pathology: Diagnostic Evaluation}

Accurate pathologic diagnosis is the cornerstone of our treatment approach. When patients come to $\mathrm{COH}$ with a diagnosis of EOC made in the community, their surgical pathology is reviewed by our gynecologic pathology team. There are four major histologic types of ovarian epithelial tumors-serous, mucinous, endometrioid, and clear cell. High grade serous carcinoma (HGSC) is the most common, and lethal histologic subtypes of all ovarian epithelial malignancies are diagnosed, often presenting at an advanced stage. A subset of these patients carry germline mutations in double-strand DNA repair genes, such as BRCA1, BRCA2, RAD51c, and PALB2. Therefore, diagnosis of HGSC carries specific prognostic, therapeutic, and genetic implications. The ovarian cancer TCGA study showed that HGSC is characterized by a near universal p53 mutation [35]. Most of the p53 mutations lead to the overexpression or deletion of the protein, and these can be detected using immunohistochemistry. 
In morphologically ambiguous cases, performing a p53 mutation analysis may be helpful, and p53 mutation status can be used to temporally track patients' tumors over time. Knowledge about the clinical and functional consequences of various p53 mutations is emerging. We perform whole-exome and RNA sequencing using the next generation sequencing platform for HGSC tumors. This allows us to define the p53 mutation profile in tumors and helps us to better understand clinical and treatment significance.

HGSC also displays genomic instability with high copy-number variations across the genome [36]. This unstable genomic landscape is a collective reflection of high tumor replication rate and the tumor cells' underlying defective DNA repair mechanisms, specifically homologous recombination repair (HRR) [37]. In HGSC, which displays homologous recombination deficiency (HRD), tumors rely on alternative but error-prone pathways, including non-homologous end-joining and single-strand annealing repair pathways [38]. Women with germline BRCA1/2 mutations are enriched for the HRD phenotype [39]. The underlying HRD phenotype explains why some HGSC patients are sensitive to platinum-based chemotherapy (carboplatin, paclitaxel, or docetaxel) or poly-(ADP-ribose)-polymerase 1 (PARP1) inhibitors (such as olaparib and niraparib). Platinum-based chemotherapy induces synthetic lethality by covalent binding with DNA, forming DNA-platinum adducts that eventually trigger double strand break. PARP1 inhibitors impede the PARP1-mediated repair of DNA single strand breaks, a component of the HRR pathway. In HGSC with underlying HRD, double strand breaks cannot be repaired efficiently and their accumulation in the genome result in cell death [38].

HGSC is diagnosed using the MD Anderson histologic 2-tier system [40,41]. Corroborating with the molecular event of p53 mutation, the diagnosis of HGSC can be further supported by performing immunohistochemical staining for p53. HGSC is staged using the current American Joint Committee on Cancer/College of American Pathologists Cancer Staging Form and the FIGO Staging System. The molecular diagnosis of ovarian cancer subtypes that correlate with prognosis may also be adopted as standard procedure in the future. Verhaak et al. analyzed the TCGA database and revealed four ovarian tumor subtypes, each associated with a different prognosis [42].

\section{Molecular Studies Available for Diagnostic or Therapeutic Decision Support and Emerging Translational Research}

We perform extensive molecular testing, including whole exome sequencing, transcriptomic sequencing, copy number information, mismatch repair (MMR) deficiency, microsatellite instability (MSI) status, tumor mutation burden (TMB), HRD, and PD-L1 protein expression levels, using paired formalin-fixed paraffin-embedded tumor tissue and patient saliva or peripheral blood. This comprehensive approach allows us to detect somatic and germline mutations, clinically actionable mutations, potential therapeutic targets, and markers to help guide checkpoint inhibitor therapy. The genomic analysis makes tailored therapy possible and informs clinical trial options that best match with patient tumor genotype.

Germline and somatic BRCA1 and BRCA2 mutations are assessed in specific clinical contexts to inform genetic counseling and therapy selection. Younger age at presentation and family history of tubo-ovarian and breast cancer malignancies are risk factors suggestive of the presence of germline cancer predisposition syndrome. Referral to a genetic counselor and establishing germline mutation information is crucial for informing patients about BRCA-related cancer risks for themselves and their family members. Most importantly, this allows patients the opportunity to access BRCA-related cancer risk reduction surgeries (e.g., risk-reducing salpingo-ophorectomy, mastectomy), where the timing of surgery can be crucial to successful risk reduction.

Germline and somatic BRCA1/2 mutation information is also important for informing PARP inhibitor eligibility in Stage II, III, and IV HGSC patients post primary treatment. The NCCN guidelines recommend screening for BRCA mutations early in the treatment course to avoid the possibility of delay in instituting PARP inhibitor therapy [43]. 
HRD positivity is determined by BRCA mutation status (deleterious or suspected deleterious) or HRD/genomic instability score (mathematically derived from genomic assessment of loss of heterozygosity, telomeric allelic imbalance, and large-scale state transitions). Due to the inherent biocomputational complexity with HRD score derivation and inter-laboratory analytic variability, most large medical centers perform HRD testing on a research basis and not for routine clinical diagnostic use.

Circulating miRNAs in blood and urine are being explored as potential early detection markers. However, the evidence on this approach is currently limited, and no consistent miRNA signatures have emerged [44-46]. The lack of reproducibility may be attributable, in part, to technical issues, such as different statistical modeling and approaches, the utilization of different miRNA detection platforms, and patient and tumor heterogeneity [46]. Besides early detection, liquid biopsy-based circulating tumor cells have been leveraged in a recent small pilot preclinical study to provide chemosensitivity information and therapy response prediction in patients presenting with recurrent ovarian cancer [47]. The quest for providing precision oncology to patients using minimally invasive liquid biopsies is expanding, and hopefully it will become a reality in the not so distant future.

With numerous genomic alterations present in HGSC, an integrative analytical approach is necessary to characterize the dominant biologic drivers of carcinogenesis, cancer progression, and prognosis. The TCGA (Cancer Genome Atlas Research Network) and CPTAC (Clinical Proteomic Tumor Analysis Consortium) investigators have paved the way for combining multiple omics in ovarian HGSC - including genomics, proteomics, and phosphoproteomics. Using transcriptomic data, TCGA has built a HGSC molecular taxonomy comprised of four subtypes: differentiated, mesenchymal, immunoreactive, and proliferative [35]. This framework was recapitulated using the proteomic data [36]. However, this molecular taxonomy does not correlate with patient survival [36]. Instead, proteomic signatures (cytoskeleton involved in invasion and migration, apoptosis, and epithelial junction/adhesion) showed more robust correlation with survival [36]. However, this proteomic signature is currently research-based only, awaiting further validation in larger independent cohorts, and is not currently used in clinical setting.

\section{Adjuvant Chemotherapy}

With the exception of patients with early-stage disease and low-grade cancers with a high cure rate, such as stage $1 \mathrm{~A}$ and $1 \mathrm{~B}$ grade 1 endometrioid ovarian cancer, mucinous carcinoma, and low grade serous carcinoma [48-50], patients with EOC who have undergone surgical debulking usually require adjuvant platinum- and taxane-based chemotherapy to reduce the risk of recurrence or prolong disease-free survival. Optimal time from surgery to initiate adjuvant chemotherapy has been shown to be 4-6 weeks $[49,51]$. Table 1 summarizes the main clinical studies of frontline treatment and maintenance of EOC. The standard adjuvant chemotherapy regimen includes: IV paclitaxel $175 \mathrm{mg} / \mathrm{m}^{2}$ and carboplatin AUC 5-6 every 3 weeks. Alternatively, dose dense weekly paclitaxel $80 \mathrm{mg} / \mathrm{m}^{2}$ and carboplatin AUC 5-6 every 3 weeks may be applied [52-55] —although this regimen has shown differing outcomes in different studies-the JGOG3016 study $[52,56]$ showed a favorable outcome over every 3-week standard regimen, while the ICON-8 [55], and GOG-262 studies [53] failed to showed a significant improvement. The MITO-7 study used weekly paclitaxel $60 \mathrm{mg} / \mathrm{m}^{2}$ and carboplatin AUC 2 for up to 18 weeks - this regimen has a high tolerance and is effective for elderly patients or those with poor performance status [54]. Single agent carboplatin is also acceptable if patients cannot tolerate the combination treatment. Docetaxel is an acceptable taxane alternative to paclitaxel with equivalent efficacy [57]. Carboplatin plus liposomal doxorubicin is also an acceptable combination for adjuvant chemotherapy when patients cannot tolerate taxanes [58,59]. Recently, bevacizumab was incorporated into the adjuvant chemotherapeutic regimen, showing improved progression-free survival and also overall survival in the high risk of progression subgroup, including those with stage IV disease and inoperable or sub-optimally debulked stage III disease (ICON-7, GOG-218) [60,61], especially in patients with ascites $[60,62,63]$. 
In patients with EOC, the peritoneal cavity is usually the primary site of recurrence. Thus, the administration of adjuvant IV/IP chemotherapy to treat residual cancer cells with highly concentrated chemotherapeutics is an attractive approach. The GOG-172 study showed that IV paclitaxel $135 \mathrm{mg} / \mathrm{m}^{2}$ on day 1 plus IP cisplatin $75-100 \mathrm{mg} / \mathrm{m}^{2}$ on day 2 and IP paclitaxel $60 \mathrm{mg} / \mathrm{m}^{2}$ on day 8 , every 3 weeks for up to six cycles, improved survival by 16 months in patients with optimally debulked stage III EOC compared with IV delivery of paclitaxel and cisplatin [27]; IP carboplatin is a suitable substitute for IP cisplatin in the GOG-252 study, as the median progression-free survival and overall survival were similar in the IP carboplatin and IP cisplatin arms [28]. However, the IV/IP chemotherapy regimen resulted in more side effects [64], including abdominal pain, catheter-related infection and blockage, and myelosuppression, all of which may delay treatment and compromise efficacy. We routinely use IV/IP adjuvant chemotherapy based on the favorable survival outcomes [27,65]. A recent publication showed that, when bevacizumab was added to IV/IV carboplatin and paclitaxel, IV/IP carboplatin and paclitaxel, or IV/IP cisplatin and paclitaxel, there was no significant difference in progression-free survival in all of these groups of patients [28]. Therefore, there is debate as to whether or not IP chemotherapy is still an acceptable option in primary adjuvant chemotherapy for patients with advanced EOC, given its higher toxicity, inconvenience, catheter complications, and uncertain long-term benefits [29]. At City of Hope, we have been treating patients with the IV/IP protocol. Due to recent advances in maintenance therapy, we are reconsidering if it is still necessary to perform the IP delivery of chemotherapeutics.

\section{Maintenance Therapy}

EOC patients who undergo surgical debulking and adjuvant chemotherapy still experience a high rate of disease recurrence. Thus, there is a need for effective maintenance therapy after adjuvant chemotherapy for patients with EOC to help prevent recurrence or prolong disease-free survival. In the past, patients who completed adjuvant chemotherapy usually underwent active surveillance with regular follow-up, labs, and imaging as needed. However, this practice was changed after the ICON-7 and GOG-218 studies showed clinical benefit by adding bevacizumab to the adjuvant chemotherapy regimen [59-62]. The ICON-7 study added bevacizumab $(7.5 \mathrm{mg} / \mathrm{kg})$ to IV paclitaxel and carboplatin on day 1 , repeated every 3 weeks for 5-6 cycles, continuing bevacizumab for up to 12 additional cycles and showed a modest prolongation of progression-free survival by 2.4 months. Overall, survival was also increased in patients with a poor prognosis $[61,66]$. The GOG-218 study added bevacizumab to IV paclitaxel and carboplatin on day 1 of cycle $2(15 \mathrm{mg} / \mathrm{kg})$, every 3 weeks for up to 22 cycles. This regimen showed a significant benefit to progression-free survival (14.1 months vs. 10.3 months, $p<0.001)$. Patients with ascites who received bevacizumab in addition to paclitaxel and carboplatin had significantly improved progression-free survival and overall survival compared to those who received paclitaxel and carboplatin alone [63]. However, maintenance with PARP inhibitors may be favored over bevacizumab due to improved survival.

Following success in treating recurrent EOC, PARP inhibitors have also recently become an attractive choice for maintenance after adjuvant chemotherapy in newly diagnosed EOC patients. Olaparib was FDA-approved (2018) for the maintenance treatment of adult patients with deleterious or suspected deleterious germline or somatic BRCA-mutated advanced EOC who are experiencing a complete or partial response to first-line platinum-based chemotherapy. This is based on the SOLO-1 study [67], a randomized, double-blind, placebo-controlled, multi-center trial that compared the efficacy of olaparib with placebo in patients with BRCA-mutated advanced ovarian, fallopian tube, or primary peritoneal cancer following first-line platinum-based chemotherapy. After a median follow-up of 41 months, the risk of disease progression or death was $70 \%$ lower with olaparib than with placebo. In May 2020, the FDA expanded the indication of olaparib to include its combination with bevacizumab for first-line maintenance treatment of adult patients with advanced EOC who have complete or partial response to first-line platinum-based chemotherapy and whose cancers are HRD-positive, defined by either a deleterious or suspected deleterious BRCA mutation and/or genomic instability score. This 
recommendation was based on the study by Ray-Coquard et al. [68], which showed that, in patients with advanced EOC receiving first-line standard therapy bevacizumab, the addition of maintenance olaparib provided a significant progression-free survival benefit, which was substantial in patients with HRD-positive tumors (37.2 vs. 17.7 months). Patients with HRD-positivity but without a BRCA mutation also had significantly improved progression-free survival (28.1 vs. 16.6 months).

Niraparib, another PARP inhibitor, was granted approval by the FDA in April 2020 as a first-line maintenance treatment of adult patients with advanced EOC who experienced a complete or partial response to first-line platinum-based chemotherapy, regardless of biomarker status. This recommendation is based on the PRIMA study [69] (Table 1) which showed that patients with newly diagnosed advanced EOC who had a response to platinum-based chemotherapy and received niraparib had significantly longer progression-free survival than those who received placebo (13.8 vs. 8.2 months), regardless of the presence or absence of HRD. We use niraparib for patients without BRCA mutation or HRD, or patients with unknown BCRA/HRD status.

Additional maintenance options are being studied in clinical trials, including new PARP inhibitors, anti-angiogenesis agents, immune checkpoint inhibitors, agents targeting other signal transduction pathways, and new rational combinations. We expect to have improved maintenance options in the future to further reduce recurrence and prolong disease-free survival. Choosing the right maintenance therapy for each patient is highly complex and benefits from multi-disciplinary discussion. At $\mathrm{COH}$, the community oncologists have access to the $\mathrm{COH}$ Gynecologic Cancer Tumor Board (discussed further below) to present their challenging cases for in-depth discussion. 
Table 1. Major clinical trials on frontline treatment of epithelial ovarian cancer

\begin{tabular}{|c|c|c|c|c|c|}
\hline Study & Patients & Experimental & Control & Progression Free Survival & Overall Survival \\
\hline JGOG $3016[52,56]$ & Stage II-IV EOC & $\begin{array}{l}\text { three-weekly carboplatin (AUC 6) and weekly } \\
\text { paclitaxel }\left(80 \mathrm{mg} / \mathrm{m}^{2}\right) \text { for six cycles }\end{array}$ & $\begin{array}{l}\text { three-weekly carboplatin (AUC 6) } \\
\text { and paclitaxel }\left(180 \mathrm{mg} / \mathrm{m}^{2} \text { ) for six }\right. \\
\text { cycles }\end{array}$ & $\begin{array}{l}28.0 \text { vs. } 17.2 \text { months; } \\
\text { HR } 0.71,95 \% \text { CI } 0.58-0.88 ; p=0.0015\end{array}$ & $\begin{array}{l}100.5 \text { vs. } 62.2 \text { months (HR } 0.79,95 \% \\
\text { CI } 0.63-0.99 ; p=0.039\end{array}$ \\
\hline MITO-7 [54] & FIGO stage IC-IV EOC & $\begin{array}{l}\text { Weekly carboplatin (AUC 2) and paclitaxel }\left(60 \mathrm{mg} / \mathrm{m}^{2}\right) \\
\text { for } 18 \text { weeks }\end{array}$ & $\begin{array}{l}\text { three-weekly carboplatin (AUC 6) } \\
\text { and paclitaxel }\left(175 \mathrm{mg} / \mathrm{m}^{2} \text { ) for six }\right. \\
\text { cycles }\end{array}$ & $\begin{array}{l}18.3 \text { vs. } 17.3 \text { months; } \\
\text { HR } 0.96,95 \% \text { CI } 0.80-1.16 ; p=0.66\end{array}$ & - \\
\hline ICON-8 [55] & FIGO stage IC-IV EOC & $\begin{array}{l}\text { Group 2: three-weekly carboplatin (AUC 5/6) and } \\
\text { weekly paclitaxel }\left(80 \mathrm{mg} / \mathrm{m}^{2} \text { ) for six cycles }\right. \\
\text { Group 3: Weekly carboplatin (AUC 6) and paclitaxel } \\
\left(60 \mathrm{mg} / \mathrm{m}^{2}\right) \text { for } 18 \text { weeks }\end{array}$ & $\begin{array}{l}\text { Group 1: three-weekly carboplatin } \\
\text { (AUC 5/6) and paclitaxel } \\
\left(175 \mathrm{~m} / \mathrm{m}^{2}\right) \text { for six cycles }\end{array}$ & $\begin{array}{l}\text { Group } 1 \text { vs. Group } 2 \text { vs. Group } 3: 17.7 \text { vs. } \\
20.8 \text { vs. } 21.0 \\
\text { Group } 2 \text { vs. Group 1: } p=0.35 \\
\text { Group } 3 \text { vs. Group 1: } \\
p=0.51\end{array}$ & - \\
\hline GOG-172 [27,65] & FIGO stage III with optimal debulking & $\begin{array}{l}\text { paclitaxel } 135 \mathrm{mg} / \mathrm{m}^{2} \text { continuous iv infusion over } 24 \mathrm{~h} \\
\text { on day } 1 \text {, cisplatin } 100 \mathrm{mg} / \mathrm{m}^{2} \text { IP on day 2, paclitaxel } \\
60 \mathrm{mg} / \mathrm{m}^{2} \text { IP on day } 8 \text { for six cycles }\end{array}$ & $\begin{array}{l}\text { paclitaxel } 135 \mathrm{mg} / \mathrm{m}^{2} \text { continuous IV } \\
\text { infusion over } 24 \mathrm{~h} \text { on day } 1 \\
\text { cisplatin } 75 \mathrm{mg} / \mathrm{m}^{2} \text { IV on day } 2 \text { for } \\
\text { six cycles }\end{array}$ & $\begin{array}{l}23.8 \text { vs. } 18.3 \text { months; } \\
\text { HR } 0.80,95 \% \text { CI } 0.64-1.00 ; p=0.05\end{array}$ & $\begin{array}{l}65.6 \text { vs. } 49.7 \text { months; HR } 0.75,95 \% \\
\text { CI, } 0.58-0.97 ; p=0.03 \\
61.8 \text { vs. } 51.4 \text { months; Adjusted HR } \\
0.77 ; 95 \% \text { CI, } 0.65-0.90 ; p=0.002 \\
\end{array}$ \\
\hline GOG-252 [28] & FIGO stage II-IV EOC & $\begin{array}{l}\text { paclitaxel } 80 \mathrm{mg} / \mathrm{m}^{2} \mathrm{IV} \text { on days } 1,8 \text {, and } 15 \text { plus } \\
\text { carboplatin AUC } 6 \text { IP on day } 1 \text { every } 21 \text { days for } \\
\text { cycles } 1-6 \text { plus bevacizumab } 15 \mathrm{mg} / \mathrm{kg} \text { IV every } \\
21 \text { days for cycles } 2-22 \text { paclitaxel } 135 \mathrm{mg} / \mathrm{m}^{2} \mathrm{IV} \text { on day } \\
1 \text { plus cisplatin } 75 \mathrm{mg} / \mathrm{m}^{2} \mathrm{IP} \text { on day } 2 \text { plus paclitaxel } \\
60 \mathrm{~m} / \mathrm{m}^{2} \mathrm{IV} \text { on day } 8 \text { every } 21 \text { days for cycles } 1-6 \\
\text { plus bevacizumab } 15 \mathrm{mg} / \mathrm{kg} \text { IV every } 21 \text { days for } \\
\text { cycles } 2-22\end{array}$ & $\begin{array}{l}\text { paclitaxel } 80 \mathrm{mg} / \mathrm{m}^{2} \text { IV on days } 1,8, \\
\text { and } 15 \text { plus carboplatin AUC } 6 \text { IV } \\
\text { on day } 1 \text { every } 21 \text { days for cycles } \\
1-6 \text { plus bevacizumab } 15 \mathrm{mg} / \mathrm{kg} \text { IV } \\
\text { every } 21 \text { days for cycles } 2-22\end{array}$ & $\begin{array}{l}\text { IV vs. IP-carboplatin vs. IP-cisplatin: } \\
24.9 \text { vs. } 27.4 \text { vs. } 26.2 \text { months } \\
\text { II-carboplatin: } \mathrm{HR} 0.93,95 \% \mathrm{CI} 0.80-1.07 \\
\text { IP-cisplatin: } \mathrm{HR} 0.98,95 \% \mathrm{CI} 0.84-1.13\end{array}$ & $\begin{array}{l}\text { IV vs. IP-carboplatin vs. } \\
\text { IP-cisplatin: } 75.5 \text { vs. } 78.9 \text { vs. } \\
72.9 \text { months } \\
\text { IP-carboplatin: } \mathrm{HR} 0.95,95 \% \text { CI } \\
0.80-1.13 \\
\text { IP-cisplatin: HR } 1.05,95 \% \text { CI; } \\
0.88-1.24 ;\end{array}$ \\
\hline GOG-262 [53] & FIGO stage III-IV EOC & $\begin{array}{l}\text { three-weekly carboplatin (AUC 6) and weekly } \\
\text { paclitaxel }\left(80 \mathrm{mg} / \mathrm{m}^{2}\right), \text { plus/ } / \text { minus three-weekly } \\
\text { bevacizumab } 15 \mathrm{mg} / \mathrm{kg} \text { for six cycles }\end{array}$ & $\begin{array}{l}\text { three-weekly carboplatin (AUC 6) } \\
\text { and paclitaxel }\left(175 \mathrm{mg} / \mathrm{m}^{2}\right) \text {, } \\
\text { plus/minus three-weekly } \\
\text { bevacizumab } 15 \mathrm{mg} / \mathrm{kg} \text { for six } \\
\text { cycles }\end{array}$ & $\begin{array}{l}\text { With bevacizumab: } \\
14.9 \text { vs. } 14.7 \text { months; } \\
\text { HR } 0.99,95 \% \text { CI } 0.83-1.20 ; p=0.60 \\
\text { Without bevacizumab: } \\
14.2 \text { vs. } 10.3 \text { months; } \\
\text { HR } 0.62,95 \% \text { CI } 0.40-0.95 ; p=0.03\end{array}$ & $\begin{array}{l}\text { With and without bevacizumab: } \\
40.2 \text { vs. } 39.0 \text { months; } \mathrm{HR} 0.94 ; 95 \% \\
\text { CI, } 0.72-1.2\end{array}$ \\
\hline SOLO-1 [67] & $\begin{array}{l}\text { FIGO stage III or IV high-grade serous or } \\
\text { endometrioid EOC patients with a } \\
\text { deleterious or suspected deleterious } \\
\text { germline or somatic BRCA1/2 mutation, } \\
\text { completed frontline platinum-based } \\
\text { chemotherapy }\end{array}$ & olaparib & placebo & $\begin{array}{l}\text { Not reached vs. } 13.8 \text { months; HR } 0.30, \\
95 \% \text { CI } 0.23-0.41) ; p<0.0001 \\
\text { 3-year: } 60 \% \text { vs. } 27 \% \text {; } \\
\text { 4-year: } 53 \% \text { vs. } 11 \%\end{array}$ & - \\
\hline PAOLA-1 [68] & $\begin{array}{l}\text { FIGO stage III or IV high-grade EOC } \\
\text { patients after first-line treatment with } \\
\text { platinum-taxane chemotherapy plus } \\
\text { bevacizumab }\end{array}$ & olaparib plus bevacizumab & placebo plus bevacizumab & $\begin{array}{l}22.1 \text { vs. } 16.6 \text { months; } \mathrm{HR} 0.59 ; 95 \% \mathrm{CI} \\
0.49-0.72 ; p<0.001 \\
\text { HRD plus BRCA mutation: } 37.2 \text { vs. } \\
17.7 \text { months; } \mathrm{HR} 0.33,95 \% \text { CI } 0.25-0.45 \\
\text { HRD minus BRCA mutation: } 28.1 \text { vs. } \\
16.6 \text { months; HR } 0.43,95 \% \text { CI } 0.28-0.66\end{array}$ & - \\
\hline PRIMA [69] & $\begin{array}{l}\text { FIGO stage III or IV high-grade serous or } \\
\text { endometrioid EOC patients after first-line } \\
\text { treatment with platinum-based } \\
\text { chemotherapy }\end{array}$ & niraparib & placebo & $\begin{array}{l}\text { Overall: } 13.8 \text { vs. } 8.2 \text { months; } \mathrm{HR} .62,95 \% \\
\text { CI } 0.50-0.76 ; p<0.001 \\
\text { HRD-positive: } 21.9 \text { vs. } 10.4 \text { months; HR } \\
0.43,95 \% \text { CI } 0.31-0.59 ; p<0.001\end{array}$ & - \\
\hline
\end{tabular}




\section{Genetic Counseling}

HGSC is a single case indicator for germline genetic testing [70]. Germline genetic testing should be considered both due to the relatively high percentage of hereditary ovarian cancer with some studies estimating that more than $20 \%$ is hereditary in etiology [71-73], and due to the potential for treatment implications [74]. Generally, it is preferable for an individual to undergo germline testing as soon as diagnosis occurs $[75,76]$. This allows ample time to obtain and disclose results, especially in the setting of a patient who may have a guarded prognosis. Urgent testing of BRCA1/2 and other breast cancer genes with high or moderate penetrance by multi-gene panel can currently be performed. While this strategy is often used for women with breast cancer undergoing surgical decision-making, it can also be employed in the gynecologic oncology setting to provide results that may affect eligibility for PARP inhibitors or other therapies in a timely manner.

Germline testing in an affected individual is the most informative strategy and can help clarify risk for relatives. Close female relatives may have increased empiric risk to develop EOC, although older studies may include some families with risk alleles that would be identified by current technology $[77,78]$. The ascertainment of a multi-generational pedigree allows both for appropriate test selection as well as for proper assessment of family structure and identification of at-risk relatives [79]. Pedigree assessment in the setting of genetic counseling can also facilitate understanding of social relationships between relatives to help develop appropriate strategies to encourage familial communication about risk.

Germline testing for women with EOC at our center typically includes evaluation via a multi-gene panel to include EOC risk genes beyond BRCA1/2, such as the mismatch repair (Lynch syndrome) genes, BRIP1, RAD51C, and RAD51D [71,80]. Beyond informing therapeutic strategy, germline testing in the setting of appropriate counseling can have significant implications for patients and family members. Germline testing can help stratify the risk of developing other cancers and guide the development of appropriate management strategies, especially as the prognosis for EOC improves with better treatment options. For example, patients with Lynch syndrome are at significantly elevated risk to develop colorectal cancer [81] and patients with pathogenic alterations in the BRCA genes are at significantly elevated risk to develop breast cancer [82]. Understanding a patient's risk may help prevent a second primary cancer, especially in the setting of well-controlled ovarian disease or in the setting where the development of a new cancer may interfere with the patient's current treatment.

Germline testing may be even more impactful in terms of implications for relatives. Identifying an ovarian cancer risk allele can allow relatives with the same allele to undergo preventative measures, such as risk-reducing salpingo-oopherectomy, which is especially relevant when screening is not effective. Moreover, in some cases, over-treatment may be avoided in relatives who do not carry the risk allele but who may have otherwise chosen to move forward with preventative measures or screening due to concerns over risk, based on family history. Many genes implicated in EOC in the setting of a monoallelic pathogenic variant also have implications for typically childhood-onset syndromes in the setting of biallelic pathogenic variants. For example, biallelic variants in BRCA1/2, BRIP1, and RAD51C [83-86] are associated with Fanconi anemia and biallelic variants in the mismatch repair genes are associated with Constitutional Mismatch Repair Deficiency syndrome [81]. Thus, individuals contemplating childbearing may also wish to learn their germline status to inform reproductive decisions.

Importantly, negative somatic testing does not obviate the need for germline testing. Reasons for this can include the loss of a germline mutation in the tumor, limited analysis of the tumor genome, and differences in variant calling between somatic and germline laboratories. Conversely, somatic testing may identify variants that are germline in origin $[87,88]$. Therefore, patients should be counseled about this possibility, and if somatic results are available, they should be reviewed to help inform germline test selection. Other genes may also be included based on clinical suspicion and the evaluation of additional personal and family history. Reevaluation should be considered over time as changes to the family history, as well as advances in the field of cancer genetics, occur [79]. 


\section{Team Medicine: Optimizing Partnerships and Clinical Research}

We have a number of initiatives to ensure the inclusion of our community partners in research, education, and the integration of research-based advances into novel therapeutics by clinical trials. We aim to personalize therapy for patients so our community physicians can recommend improved therapy considerations, including clinical trials beyond the standard of care. One way we achieve this is via comprehensive molecular testing. All EOC patients at $\mathrm{COH}$ undergo GEM ExTra ${ }^{\circledR}$ testing (facilitated by TGen, a COH affiliate). This test reports clinically actionable mutations, copy number alterations, transcript variants, and fusions, detected in any gene in patient DNA or RNA. The goal is to uncover true tumor-specific (somatic) alterations by comparing the sequence of the tumor against the paired normal DNA from each patient. The test also includes whole-transcriptome RNA profiling, interrogating the patient's tumor transcriptome for fusions and transcriptional variants known to be relevant to cancer (e.g., EGFR vIII). Each tumor's cancer-specific alterations are then queried against a proprietary knowledge base algorithm to identify potential therapeutic associations. The final report provides the physician with a list of FDA-approved agents that are associated with tumor-specific DNA alterations, as well as biomarker summaries on the variants found and tumor-specific evidence for drug matches, including matches with investigational agents, as available on clinicaltrials.gov. The results are reviewed by our multidisciplinary gynecologic cancer research team to aid in treatment decision-making, highlight on-going studies and identify study candidates.

Our current clinical research portfolio in the frontline management of EOC focuses on developing superior treatment options for patients that reduce recurrence and prolong disease-free survival. We are exploring the use of HIPEC and PIPAC in the clinical trial setting as well as novel drug combinations that help to tailor and personalize treatment for superior results. Our HIPEC trial includes studying the molecular changes triggered by HIPEC to identify molecular signatures of response. Our PIPAC trial is the first in the United States to study aerosolized, pressurized chemotherapy for patients with peritoneal carcinomatosis, including ovarian cancer. Our community oncologists play an important role in these studies by referring patients, thereby allowing us to complete accrual expeditiously.

\section{Summary}

Management of EOC requires a multi-disciplinary approach, drawing on clinical expertise and collaboration combined with community practice and cutting edge clinical and translational research. Our goal is to understand the biology of this disease, advance therapy and connect our patients with the optimal treatment that offers the best possible outcomes.

Author Contributions: Conceptualization, E.W.W., C.H.W., S.L., S.J.-J.L., S.S. (Susan Shehayeb), S.G., R.L., S.S. (Siamak Saadat), J.S.; validation, E.W.W., M.C. and L.R.-R.; writing-original draft preparation, E.W.W., C.H.W., S.L., S.J.-J.L., S.S. (Susan Shehayeb), S.G., R.L., S.S. (Siamak Saadat), J.S.; writing-review and editing, E.W.W., C.H.W., S.L., S.J.-J.L., S.S. (Susan Shehayeb), T.D., E.S.H., D.S., S.W., M.C. and L.R.-R.; supervision, E.W.W. and L.R.-R.; project administration, E.W.W.; funding acquisition, E.W.W. All authors have read and agreed to the published version of the manuscript.

Funding: This research received no external funding.

Acknowledgments: The authors thank Nicola Welch, CMPP for assistance with writing and editing the manuscript. This work was supported by the National Cancer Institute of the National Institutes of Health under award number K12CA001727. The content is solely the responsibility of the authors and does not necessarily represent the official views of the National Institutes of Health.

Conflicts of Interest: The authors declare no conflict of interest.

\section{References}

1. Board PDQATE. Ovarian Epithelial, Fallopian Tube, and Primary Peritoneal Cancer Treatment (PDQ(R)): Health Professional Version; PDQ Cancer Information Summaries; National Cancer Institute: Bethesda, MD, USA, 2002.

2. Siegel, R.L.; Miller, K.D.; Jemal, A. Cancer statistics, 2020. CA A Cancer J. Clin. 2020, 70, 145-164. [CrossRef] 
3. Nebgen, D.R.; Lu, K.H.; Bast, R.C., Jr. Novel Approaches to Ovarian Cancer Screening. Curr. Oncol. Rep. 2019, 21, 75. [CrossRef]

4. Howlader, N.N.A.; Krapcho, M.; Miller, D.; Brest, A.; Yu, M.; Ruhl, J.; Tatalovich, Z.; Mariotto, A.; Lewis, D.R.; Chen, H.S.; et al. SEER Cancer Statistics Review, 1975-2017; National Cancer Institute: Bethesda, MD, USA; Available online: https://seer.cancer.gov/csr/1975_2017/ (accessed on 25 August 2020).

5. Cliby, W.A.; Powell, M.A.; Al-Hammadi, N.; Chen, L.; Miller, J.P.; Roland, P.Y.; Mutch, D.G.; Bristow, R.E. Ovarian cancer in the United States: Contemporary patterns of care associated with improved survival. Gynecol. Oncol. 2015, 136, 11-17. [CrossRef] [PubMed]

6. Hoskins, W.J.; McGuire, W.P.; Brady, M.; Homesley, H.D.; Creasman, W.T.; Berman, M.; Ball, H.; Berek, J.S. The effect of diameter of largest residual disease on survival after primary cytoreductive surgery in patients with suboptimal residual epithelial ovarian carcinoma. Am. J. Obs. Gynecol. 1994, 170, 974-979. [CrossRef]

7. Eisenkop, S.M.; Friedman, R.L.; Wang, H.J. Complete cytoreductive surgery is feasible and maximizes survival in patients with advanced epithelial ovarian cancer: A prospective study. Gynecol. Oncol. 1998, 69, 103-108. [CrossRef] [PubMed]

8. Allen, D.G.; Heintz, A.P.; Touw, F.W. A meta-analysis of residual disease and survival in stage III and IV carcinoma of the ovary. Eur. J. Gynaecol. Oncol. 1995, 16, 349-356. [PubMed]

9. Chi, D.S.; Eisenhauer, E.L.; Lang, J.; Huh, J.; Haddad, L.; Abu-Rustum, N.R.; Sonoda, Y.; Levine, D.; Hensley, M.; Barakat, R. What is the optimal goal of primary cytoreductive surgery for bulky stage IIIC epithelial ovarian carcinoma (EOC)? Gynecol. Oncol. 2006, 103, 559-564. [CrossRef]

10. Winter, W.E., 3rd; Maxwell, G.L.; Tian, C.; Carlson, J.W.; Ozols, R.F.; Rose, P.G.; Markman, M.; Armstrong, D.K.; Muggia, F; McGuire, W.P. Prognostic factors for stage III epithelial ovarian cancer: A Gynecologic Oncology Group Study. J. Clin. Oncol. Off. J. Am. Soc. Clin. Oncol. 2007, 25, 3621-3627. [CrossRef]

11. Wimberger, P.; Lehmann, N.; Kimmig, R.; Burges, A.; Meier, W.; Du Bois, A. Prognostic factors for complete debulking in advanced ovarian cancer and its impact on survival. An exploratory analysis of a prospectively randomized phase III study of the Arbeitsgemeinschaft Gynaekologische Onkologie Ovarian Cancer Study Group (AGO-OVAR). Gynecol. Oncol. 2007, 106, 69-74.

12. Bristow, R.E.; Tomacruz, R.S.; Armstrong, D.K.; Trimble, E.L.; Montz, F.J. Survival effect of maximal cytoreductive surgery for advanced ovarian carcinoma during the platinum era: A meta-analysis. J. Clin. Oncol. Off. J. Am. Soc. Clin. Oncol. 2002, 20, 1248-1259. [CrossRef]

13. Teramukai, S.; Ochiai, K.; Tada, H.; Fukushima, M. Japan Multinational Trial Organization OC. PIEPOC: A new prognostic index for advanced epithelial ovarian cancer-Japan Multinational Trial Organization OC01-01. J. Clin. Oncol. Off. J. Am. Soc. Clin. Oncol. 2007, 25, 3302-3306. [CrossRef] [PubMed]

14. Chang, S.J.; Hodeib, M.; Chang, J.; Bristow, R.E. Survival impact of complete cytoreduction to no gross residual disease for advanced-stage ovarian cancer: A meta-analysis. Gynecol. Oncol. 2013, 130, $493-498$. [CrossRef] [PubMed]

15. Eisenkop, S.M.; Spirtos, N.M.; Lin, W.C. “Optimal” cytoreduction for advanced epithelial ovarian cancer: A commentary. Gynecol. Oncol. 2006, 103, 329-335. [CrossRef] [PubMed]

16. Winter, W.E., 3rd; Maxwell, G.L.; Tian, C.; Sundborg, M.J.; Rose, G.S.; Rose, P.G.; Rubin, S.C.; Muggia, F.; McGuire, W.P. Tumor residual after surgical cytoreduction in prediction of clinical outcome in stage IV epithelial ovarian cancer: A Gynecologic Oncology Group Study. J. Clin. Oncol. Off. J. Am. Soc. Clin. Oncol. 2008, 26, 83-89. [CrossRef] [PubMed]

17. Eisenhauer, E.L.; Abu-Rustum, N.R.; Sonoda, Y.; Aghajanian, C.; Barakat, R.R.; Chi, D.S. The effect of maximal surgical cytoreduction on sensitivity to platinum-taxane chemotherapy and subsequent survival in patients with advanced ovarian cancer. Gynecol. Oncol. 2008, 108, 276-281. [CrossRef] [PubMed]

18. Hoskins, W.J. Epithelial ovarian carcinoma: Principles of primary surgery. Gynecologic Oncol. 1994, 55 (3 Pt 2), S91-S96. [CrossRef]

19. Elattar, A.; Bryant, A.; Winter-Roach, B.A.; Hatem, M.; Naik, R. Optimal primary surgical treatment for advanced epithelial ovarian cancer. Cochrane Database Syst. Rev. 2011, 2011, Cd007565. [CrossRef]

20. Wright, J.D.; Chen, L.; Hou, J.Y.; Burke, W.M.; Tergas, A.I.; Ananth, C.V.; Neugut, A.I.; Hershman, D.L. Association of Hospital Volume and Quality of Care With Survival for Ovarian Cancer. Obstet. Gynecol. 2017, 130, 545-553. [CrossRef] 
21. Rutten, M.J.; Gaarenstroom, K.N.; Van Gorp, T.; van Meurs, H.S.; Arts, H.J.; Bossuyt, P.M.; Ter Brugge, H.G.; Hermans, R.H.; Opmeer, B.C.; Pijnenborg, J.M.; et al. Laparoscopy to predict the result of primary cytoreductive surgery in advanced ovarian cancer patients (LapOvCa-trial): A multicentre randomized controlled study. BMC Cancer 2012, 12, 31. [CrossRef]

22. Rutten, M.J.; van Meurs, H.S.; van de Vrie, R.; Gaarenstroom, K.N.; Naaktgeboren, C.A.; van Gorp, T.; Ter Brugge, H.G.; Hofhuis, W.; Schreuder, H.W.; Arts, H.J.; et al. Laparoscopy to Predict the Result of Primary Cytoreductive Surgery in Patients With Advanced Ovarian Cancer: A Randomized Controlled Trial. J. Clin. Oncol. Off. J. Am. Soc. Clin. Oncol. 2017, 35, 613-621. [CrossRef]

23. Fagotti, A.; Ferrandina, G.; Fanfani, F.; Ercoli, A.; Lorusso, D.; Rossi, M.; Scambia, G. A laparoscopy-based score to predict surgical outcome in patients with advanced ovarian carcinoma: A pilot study. Ann. Surg. Oncol. 2006, 13, 1156-1161. [CrossRef] [PubMed]

24. Wright, A.A.; Bohlke, K.; Armstrong, D.K.; Bookman, M.A.; Cliby, W.A.; Coleman, R.L.; Dizon, D.S.; Kash, J.J.; Meyer, L.A.; Moore, K.N.; et al. Neoadjuvant Chemotherapy for Newly Diagnosed, Advanced Ovarian Cancer: Society of Gynecologic Oncology and American Society of Clinical Oncology Clinical Practice Guideline. J. Clin. Oncol. Off. J. Am. Soc. Clin. Oncol. 2016, 34, 3460-3473. [CrossRef] [PubMed]

25. Harter, P.; Sehouli, J.; Lorusso, D.; Reuss, A.; Vergote, I.; Marth, C.; Kim, J.-W.; Raspagliesi, F.; Lampe, B.; Aletti, G.; et al. A Randomized Trial of Lymphadenectomy in Patients with Advanced Ovarian Neoplasms. N. Engl. J. Med. 2019, 380, 822-832. [CrossRef] [PubMed]

26. Walker, J.L.; Armstrong, D.K.; Huang, H.Q.; Fowler, J.; Webster, K.; Burger, R.A.; Clarke-Pearson, D. Intraperitoneal catheter outcomes in a phase III trial of intravenous versus intraperitoneal chemotherapy in optimal stage III ovarian and primary peritoneal cancer: A Gynecologic Oncology Group Study. Gynecol. Oncol. 2006, 100, 27-32. [CrossRef] [PubMed]

27. Armstrong, D.K.; Bundy, B.; Wenzel, L.; Huang, H.Q.; Baergen, R.; Lele, S.; Copeland, L.J.; Walker, J.; Burger, R.A. Intraperitoneal cisplatin and paclitaxel in ovarian cancer. N. Engl. J. Med. 2006, 354, 34-43. [CrossRef] [PubMed]

28. Walker, J.L.; Brady, M.F.; Wenzel, L.; Fleming, G.F.; Huang, H.Q.; DiSilvestro, P.A.; Fujiwara, K.; Alberts, D.S.; Zheng, W.; Tewari, K.S.; et al. Randomized Trial of Intravenous Versus Intraperitoneal Chemotherapy Plus Bevacizumab in Advanced Ovarian Carcinoma: An NRG Oncology/Gynecologic Oncology Group Study. J. Clin. Oncol. Off. J. Am. Soc. Clin. Oncol. 2019, 37, 1380-1390. [CrossRef] [PubMed]

29. Monk, B.J.; Chan, J.K. Is intraperitoneal chemotherapy still an acceptable option in primary adjuvant chemotherapy for advanced ovarian cancer? Ann. Oncol. Off. J. Eur. Soc. Med. Oncol. 2017, 28 (Suppl. 8), viii40-viii45. [CrossRef]

30. van Driel, W.J.; Koole, S.N.; Sikorska, K.; Schagen van Leeuwen, J.H.; Schreuder, H.W.R.; Hermans, R.H.M.; De Hingh, I.H.; Van Der Velden, J.; Arts, H.J.; Massuger, L.F.; et al. Hyperthermic Intraperitoneal Chemotherapy in Ovarian Cancer. N. Engl. J. Med. 2018, 378, 230-240. [CrossRef]

31. Bouchard-Fortier, G.; Cusimano, M.C.; Fazelzad, R.; Sajewycz, K.; Lu, L.; Espin-Garcia, O.; May, T.; Bouchard-Fortier, A.; Ferguson, S.E. Oncologic outcomes and morbidity following heated intraperitoneal chemotherapy at cytoreductive surgery for primary epithelial ovarian cancer: A systematic review and meta-analysis. Gynecol. Oncol. 2020, 158, 218-228. [CrossRef]

32. Pletcher, E.; Gleeson, E.; Labow, D. Peritoneal Cancers and Hyperthermic Intraperitoneal Chemotherapy. Surg. Clin. N. Am. 2020, 100, 589-613. [CrossRef]

33. Nadiradze, G.; Horvath, P.; Sautkin, Y.; Archid, R.; Weinreich, F.J.; Königsrainer, A.; Reymond, M.A. Overcoming Drug Resistance by Taking Advantage of Physical Principles: Pressurized Intraperitoneal Aerosol Chemotherapy (PIPAC). Cancers 2019, 12, 34. [CrossRef]

34. Tate, S.J.; Torkington, J. Pressurized intraperitoneal aerosol chemotherapy: A review of the introduction of a new surgical technology using the IDEAL framework. BJS Open 2020, 4, 206-215. [CrossRef] [PubMed]

35. Cancer Genome Atlas Research Network. Integrated genomic analyses of ovarian carcinoma. Nature 2011, 474, 609-615. [CrossRef] [PubMed]

36. Zhang, H.; Liu, T.; Zhang, Z.; Payne, S.H.; Zhang, B.; McDermott, J.E.; Zhou, J.-Y.; Petyuk, V.A.; Chen, L.; Ray, D.; et al. Integrated Proteogenomic Characterization of Human High-Grade Serous Ovarian Cancer. Cell 2016, 166, 755-765. [CrossRef] [PubMed]

37. Gee, M.E.; Faraahi, Z.; McCormick, A.; Edmondson, R.J. DNA damage repair in ovarian cancer: Unlocking the heterogeneity. J. Ovarian Res. 2018, 11, 50. [CrossRef] [PubMed] 
38. Milanesio, M.C.; Giordano, S.; Valabrega, G. Clinical Implications of DNA Repair Defects in High-Grade Serous Ovarian Carcinomas. Cancers 2020, 12, 1315. [CrossRef]

39. Takaya, H.; Nakai, H.; Takamatsu, S.; Mandai, M.; Matsumura, N. Homologous recombination deficiency status-based classification of high-grade serous ovarian carcinoma. Sci. Rep. 2020, 10, 2757. [CrossRef]

40. Bodurka, D.C.; Deavers, M.T.; Tian, C.; Sun, C.C.; Malpica, A.; Coleman, R.L.; Lu, K.H.; Sood, A.K.; Birrer, M.J.; Ozols, R.; et al. Reclassification of serous ovarian carcinoma by a 2-tier system: A Gynecologic Oncology Group Study. Cancer 2012, 118, 3087-3094. [CrossRef]

41. Malpica, A.; Deavers, M.T.; Lu, K.; Bodurka, D.C.; Atkinson, E.N.; Gershenson, D.M.; Silva, E.G. Grading ovarian serous carcinoma using a two-tier system. Am. J. Surg. Pathol. 2004, 28, 496-504. [CrossRef]

42. Verhaak, R.G.; Tamayo, P.; Yang, J.Y.; Hubbard, D.; Zhang, H.; Creighton, C.J.; Fereday, S.; Lawrence, M.; Carter, S.L.; Mermel, C.; et al. Prognostically relevant gene signatures of high-grade serous ovarian carcinoma. J. Clin. Investig. 2013, 123, 517-525. [CrossRef]

43. Armstrong, D.K.; Alvarez, R.D.; Bakkum-Gamez, J.N.; Barroilhet, L.; Behbakht, K.; Berchuck, A.; Berek, J.S.; Chen, L.-M.; Cristea, M.; DeRosa, M.; et al. NCCN Guidelines Insights: Ovarian Cancer, Version 1.2019. J. Natl. Compr. Cancer Netw. 2019, 17, 896-909. [CrossRef] [PubMed]

44. Yokoi, A.; Yoshioka, Y.; Hirakawa, A.; Yamamoto, Y.; Ishikawa, M.; Ikeda, S.I.; Kato, T.; Niimi, K.; Kajiyama, H.; Kikkawa, F.; et al. A combination of circulating miRNAs for the early detection of ovarian cancer. Oncotarget 2017, 8, 89811-89823. [CrossRef] [PubMed]

45. Otsuka, I.; Matsuura, T. Screening and Prevention for High-Grade Serous Carcinoma of the Ovary Based on Carcinogenesis-Fallopian Tube- and Ovarian-Derived Tumors and Incessant Retrograde Bleeding. Diagnostics 2020, 10, 120. [CrossRef] [PubMed]

46. Elias, K.M.; Fendler, W.; Stawiski, K.; Fiascone, S.J.; Vitonis, A.F.; Berkowitz, R.S.; Frendl, G.; Konstantinopoulos, P.A.; Crum, C.P.; Kedzierska, M.; et al. Diagnostic potential for a serum miRNA neural network for detection of ovarian cancer. eLife 2017, 6, e28932. [CrossRef] [PubMed]

47. Guadagni, S.; Clementi, M.; Masedu, F.; Fiorentini, G.; Sarti, D.; Deraco, M.; Kusamura, S.; Papasotiriou, I.; Apostolou, P.; Aigner, K.R.; et al. A Pilot Study of the Predictive Potential of Chemosensitivity and Gene Expression Assays Using Circulating Tumour Cells from Patients with Recurrent Ovarian Cancer. Int. J. Mol. Sci. 2020, 21, 4813. [CrossRef]

48. Young, R.C.; Walton, L.A.; Ellenberg, S.S.; Homesley, H.D.; Wilbanks, G.D.; Decker, D.G.; Miller, A.; Park, R.; Major, F. Adjuvant therapy in stage I and stage II epithelial ovarian cancer. Results of two prospective randomized trials. N. Eng. J. Med. 1990, 322, 1021-1027. [CrossRef]

49. Winter-Roach, B.A.; Kitchener, H.C.; Lawrie, T.A. Adjuvant (post-surgery) chemotherapy for early stage epithelial ovarian cancer. Cochrane Database Syst. Rev. 2012, 3, Cd004706.

50. Hogberg, T.; Glimelius, B.; Nygren, P. A systematic overview of chemotherapy effects in ovarian cancer. Acta Oncolog. 2001, 40,340-360. [CrossRef]

51. Chan, J.K.; Java, J.J.; Fuh, K.; Monk, B.J.; Kapp, D.S.; Herzog, T.; Bell, J.; Young, R. The association between timing of initiation of adjuvant therapy and the survival of early stage ovarian cancer patients-An analysis of NRG Oncology/Gynecologic Oncology Group trials. Gynecol. Oncol. 2016, 143, 490-495. [CrossRef]

52. Harano, K.; Terauchi, F.; Katsumata, N.; Takahashi, F.; Yasuda, M.; Takakura, S.; Takano, M.; Yamamoto, Y.; Sugiyama, T. Quality-of-life outcomes from a randomized phase III trial of dose-dense weekly paclitaxel and carboplatin compared with conventional paclitaxel and carboplatin as a first-line treatment for stage II-IV ovarian cancer: Japanese Gynecologic Oncology Group Trial (JGOG3016). Ann. Oncol. Off. J. Eur. Soc. Med.Oncol. 2014, 25, 251-257.

53. Chan, J.K.; Brady, M.F.; Penson, R.T.; Huang, H.; Birrer, M.J.; Walker, J.L.; DiSilvestro, P.A.; Rubin, S.C.; Martin, L.P.; Davidson, S.A.; et al. Weekly vs. Every-3-Week Paclitaxel and Carboplatin for Ovarian Cancer. N. Eng. J. Med. 2016, 374, 738-748. [CrossRef] [PubMed]

54. Pignata, S.; Scambia, G.; Katsaros, D.; Gallo, C.; Pujade-Lauraine, E.; De Placido, S.; Bologna, A.; Weber, B.; Raspagliesi, F.; Panici, P.B.; et al. Carboplatin plus paclitaxel once a week versus every 3 weeks in patients with advanced ovarian cancer (MITO-7): A randomised, multicentre, open-label, phase 3 trial. Lancet Oncol. 2014, 15, 396-405. [CrossRef] 
55. Clamp, A.R.; James, E.C.; McNeish, I.A.; Dean, A.; Kim, J.W.; O’Donnell, D.M.; Hook, J.; Coyle, C.; Blagden, S.; Brenton, J.D.; et al. Weekly dose-dense chemotherapy in first-line epithelial ovarian, fallopian tube, or primary peritoneal carcinoma treatment (ICON8): Primary progression free survival analysis results from a GCIG phase 3 randomised controlled trial. Lancet 2019, 394, 2084-2095. [CrossRef]

56. Katsumata, N.; Yasuda, M.; Isonishi, S.; Takahashi, F.; Michimae, H.; Kimura, E.; Aoki, D.; Jobo, T.; Kodama, S.; Terauchi, F.; et al. Long-term results of dose-dense paclitaxel and carboplatin versus conventional paclitaxel and carboplatin for treatment of advanced epithelial ovarian, fallopian tube, or primary peritoneal cancer (JGOG 3016): A randomised, controlled, open-label trial. Lancet Oncol. 2013, 14, 1020-1026. [CrossRef]

57. Hsu, Y.; Sood, A.K.; Sorosky, J.I. Docetaxel versus paclitaxel for adjuvant treatment of ovarian cancer: Case-control analysis of toxicity. Am. J. Clin. Oncol. 2004, 27, 14-18. [CrossRef]

58. Nguyen, J.; Solimando, D.A., Jr.; Waddell, J.A. Carboplatin and Liposomal Doxorubicin for Ovarian Cancer. Hosp. Pharm. 2016, 51, 442-449. [CrossRef]

59. Pignata, S.; Scambia, G.; Ferrandina, G.; Savarese, A.; Sorio, R.; Breda, E.; Gebbia, V.; Musso, P.; Frigerio, L.; Del Medico, P.; et al. Carboplatin plus paclitaxel versus carboplatin plus pegylated liposomal doxorubicin as first-line treatment for patients with ovarian cancer: The MITO-2 randomized phase III trial. J. Clin. Oncol. Off. J. Am. Soc. Clin. Oncol. 2011, 29, 3628-3635. [CrossRef]

60. Burger, R.A.; Brady, M.F.; Rhee, J.; Sovak, M.A.; Kong, G.; Nguyen, H.P.; Bookman, M.A. Independent radiologic review of the Gynecologic Oncology Group Study 0218, a phase III trial of bevacizumab in the primary treatment of advanced epithelial ovarian, primary peritoneal, or fallopian tube cancer. Gynecol. Oncol. 2013, 131, 21-26. [CrossRef]

61. Perren, T.J.; Swart, A.M.; Pfisterer, J.; Ledermann, J.A.; Pujade-Lauraine, E.; Kristensen, G.; Carey, M.S.; Beale, P.; Cervantes, A.; Kurzeder, C.; et al. A phase 3 trial of bevacizumab in ovarian cancer. N. Eng. J. Med. 2011, 365, 2484-2496. [CrossRef]

62. Burger, R.A.; Brady, M.; Bookman, M.A.; Fleming, G.F.; Monk, B.J.; Huang, H.; Mannel, R.S.; Homesley, H.D.; Fowler, J.; Greer, B.E.; et al. Incorporation of bevacizumab in the primary treatment of ovarian cancer. N. Eng. J. Med. 2011, 365, 2473-2483. [CrossRef]

63. Ferriss, J.S.; Java, J.J.; Bookman, M.A.; Fleming, G.F.; Monk, B.J.; Walker, J.L.; Homesley, H.D.; Fowler, J.; Greer, B.E.; Boente, M.P.; et al. Ascites predicts treatment benefit of bevacizumab in front-line therapy of advanced epithelial ovarian, fallopian tube and peritoneal cancers: An NRG Oncology/GOG study. Gynecol. Oncol. 2015, 139, 17-22. [CrossRef]

64. Wenzel, L.B.; Huang, H.Q.; Armstrong, D.K.; Walker, J.L.; Cella, D. Health-related quality of life during and after intraperitoneal versus intravenous chemotherapy for optimally debulked ovarian cancer: A Gynecologic Oncology Group Study. J. Clin. Oncol. Off. J. Am. Soc. Clin. Oncol. 2007, 25, 437-443. [CrossRef] [PubMed]

65. Tewari, D.; Java, J.J.; Salani, R.; Armstrong, D.K.; Markman, M.; Herzog, T.; Monk, B.J.; Chan, J.K. Long-term survival advantage and prognostic factors associated with intraperitoneal chemotherapy treatment in advanced ovarian cancer: A gynecologic oncology group study. J. Clin. Oncol. Off. J. Am. Soc. Clin. Oncol. 2015, 33, 1460-1466. [CrossRef]

66. Oza, A.M.; Cook, A.D.; Pfisterer, J.; Embleton, A.; Ledermann, J.A.; Pujade-Lauraine, E.; Kristensen, G.; Carey, M.S.; Beale, P.; Cervantes, A.; et al. Standard chemotherapy with or without bevacizumab for women with newly diagnosed ovarian cancer (ICON7): Overall survival results of a phase 3 randomised trial. Lancet Oncol. 2015, 16, 928-936. [CrossRef]

67. Moore, K.N.; Colombo, N.; Scambia, G.; Kim, B.-G.; Oaknin, A.; Friedlander, M.; Lisyanskaya, A.; Floquet, A.; Leary, A.; Sonke, G.S.; et al. Maintenance Olaparib in Patients with Newly Diagnosed Advanced Ovarian Cancer. N. Eng. J. Med. 2018, 379, 2495-2505. [CrossRef] [PubMed]

68. Ray-Coquard, I.; Pautier, P.; Pignata, S.; Pérol, D.; González-Martín, A.; Berger, R.; Fujiwara, K.; Vergote, I.; Colombo, N.; Mäenpää, J.; et al. Olaparib plus Bevacizumab as First-Line Maintenance in Ovarian Cancer. N. Eng. J. Med. 2019, 381, 2416-2428. [CrossRef] [PubMed]

69. González-Martín, A.; Pothuri, B.; Vergote, I.; Christensen, R.D.; Graybill, W.; Mirza, M.R.; McCormick, C.; Lorusso, D.; Hoskins, P.; Freyer, G.; et al. Niraparib in Patients with Newly Diagnosed Advanced Ovarian Cancer. N. Engl. J. Med. 2019, 381, 2391-2402. [CrossRef]

70. Daly, M.B.; Pilarski, R.; Yurgelun, M.B.; Berry, M.P.; Buys, S.S.; Dickson, P.; Domchek, S.M.; Elkhanany, A.; Friedman, S.; Garber, J.E.; et al. NCCN Guidelines Insights: Genetic/Familial High-Risk Assessment: Breast, Ovarian, and Pancreatic, Version 1.2020. J. Natl. Compr. Cancer Netw. 2020, 18, 380-391. [CrossRef] 
71. Walsh, T.; Casadei, S.; Lee, M.K.; Pennil, C.C.; Nord, A.S.; Thornton, A.M.; Roeb, W.; Agnew, K.J.; Stray, S.M.; Wickramanayake, A.; et al. Mutations in 12 genes for inherited ovarian, fallopian tube, and peritoneal carcinoma identified by massively parallel sequencing. Proc. Natl. Acad. Sci. USA 2011, 108, 18032-18037. [CrossRef]

72. Zhang, S.; Royer, R.; Li, S.; McLaughlin, J.R.; Rosen, B.; Risch, H.A.; Fan, I.; Bradley, L.; Shaw, P.A.; Narod, S.A. Frequencies of BRCA1 and BRCA2 mutations among 1,342 unselected patients with invasive ovarian cancer. Gynecol. Oncol. 2011, 121, 353-357. [CrossRef]

73. Pal, T.; Permuth-Wey, J.; Betts, J.A.; Krischer, J.P.; Fiorica, J.; Arango, H.; Lapolla, J.; Hoffman, M.; Martino, M.A.; Wakeley, K.; et al. BRCA1 and BRCA2 mutations account for a large proportion of ovarian carcinoma cases. Cancer 2005, 104, 2807-2816. [CrossRef] [PubMed]

74. Fong, P.C.; Boss, D.S.; Yap, T.A.; Tutt, A.; Wu, P.; Mergui-Roelvink, M.; Mortimer, P.; Swaisland, H.; Lau, A.; O'Connor, M.J.; et al. Inhibition of poly(ADP-ribose) polymerase in tumors from BRCA mutation carriers. N. Engl. J. Med. 2009, 361, 123-134. [CrossRef] [PubMed]

75. Novetsky, A.; Smith, K.; Babb, S.A.; Jeffe, N.B.; Hagemann, A.R.; Thaker, P.H.; Powell, M.A.; Mutch, D.G.; Massad, L.S.; Zighelboim, I. Timing of referral for genetic counseling and genetic testing in patients with ovarian, fallopian tube, or primary peritoneal carcinoma. Int. J. Gynecol. Cancer 2013, 23, 1016-1021. [CrossRef] [PubMed]

76. Neviere, Z.; De La Motte Rouge, T.; Floquet, A.; Johnson, A.; Berthet, P.; Joly, F. How and when to refer patients for oncogenetic counseling in the era of PARP inhibitors. Adv. Med. Oncol. 2020, 12, 1758835919897530. [CrossRef]

77. Stratton, J.F.; Pharoah, P.; Smith, S.K.; Easton, D.; Ponder, B.A. A systematic review and meta-analysis of family history and risk of ovarian cancer. Br. J. Obstet. Gynaecol. 1998, 105, 493-499. [CrossRef] [PubMed]

78. Jervis, S.; Song, H.; Lee, A.; Dicks, E.; Harrington, P.; Baynes, C.; Manchanda, R.; Easton, U.F.; Jacobs, I.; Pharoah, P.P.D.; et al. A risk prediction algorithm for ovarian cancer incorporating BRCA1, BRCA2, common alleles and other familial effects. J. Med. Genet. 2015, 52, 465-475. [CrossRef]

79. Lu, K.H.; Wood, M.E.; Daniels, M.S.; Burke, C.; Ford, J.; Kauff, N.D.; Kohlmann, W.; Lindor, N.M.; Mulvey, T.M.; Robinson, L.; et al. American Society of Clinical Oncology Expert Statement: Collection and use of a cancer family history for oncology providers. J. Clin. Oncol. Off. J. Am. Soc. Clin. Oncol. 2014, 32, 833-840. [CrossRef]

80. Desmond, A.; Kurian, A.W.; Gabree, M.; Mills, M.A.; Anderson, M.J.; Kobayashi, Y.; Horick, N.; Yang, S.; Shannon, K.M.; Tung, N.; et al. Clinical Actionability of Multigene Panel Testing for Hereditary Breast and Ovarian Cancer Risk Assessment. JAMA Oncol. 2015, 1, 943-951. [CrossRef]

81. Wimmer, K.; Kratz, C.P. Constitutional mismatch repair-deficiency syndrome. Haematologica 2010, 95, 699-701. [CrossRef]

82. Ford, D.; Easton, D.; Stratton, M.; Narod, S.; Goldgar, D.; Devilee, P.; Bishop, D.T.; Weber, B.; Lenoir, G.; Chang-Claude, J.; et al. Genetic heterogeneity and penetrance analysis of the BRCA1 and BRCA2 genes in breast cancer families. The Breast Cancer Linkage Consortium. Am. J. Hum. Genet. 1998, 62, 676-689. [CrossRef]

83. Rafnar, T.; Gudbjartsson, D.F.; Sulem, P.; Jonasdottir, A.; Sigurdsson, A.; Jonasdottir, A.; Besenbacher, S.; Lundin, P.; Stacey, S.N.; Gudmundsson, J.; et al. Mutations in BRIP1 confer high risk of ovarian cancer. Nat. Genet. 2011, 43, 1104-1107. [CrossRef] [PubMed]

84. Vaz, F.; Hanenberg, H.; Schuster, B.; Barker, K.; Wiek, C.; Erven, V.; Neveling, K.; Endt, D.; Kesterton, I.; Autore, F.; et al. Mutation of the RAD51C gene in a Fanconi anemia-like disorder. Nat. Genet. 2010, 42, 406-409. [CrossRef] [PubMed]

85. Sawyer, S.L.; Tian, L.; Kähkönen, M.; Schwartzentruber, J.; Kircher, M.; Majewski, J.; Dyment, D.A.; Innes, A.M.; Boycott, K.M.; Moreau, L.A.; et al. Biallelic mutations in BRCA1 cause a new Fanconi anemia subtype. Cancer Discov. 2015, 5, 135-142. [CrossRef] [PubMed]

86. Wagner, J.E.; Tolar, J.; Levran, O.; Scholl, T.; Deffenbaugh, A.; Satagopan, J.; Ben-Porat, L.; Mah, K.; Batish, S.D.; Kutler, D.I.; et al. Germline mutations in BRCA2: Shared genetic susceptibility to breast cancer, early onset leukemia, and Fanconi anemia. Blood 2004, 103, 3226-3229. [CrossRef] [PubMed] 
87. Ngeow, J.; Eng, C. Precision medicine in heritable cancer: When somatic tumour testing and germline mutations meet. NPJ Genomic Med. 2016, 1, 15006. [CrossRef]

88. Slavin, T.P.; Banks, K.C.; Chudova, D.; Oxnard, G.R.; Odegaard, J.I.; Nagy, R.J.; Tsang, K.W.; Neuhausen, S.L.; Gray, S.W.; Cristofanilli, M.; et al. Identification of Incidental Germline Mutations in Patients With Advanced Solid Tumors Who Underwent Cell-Free Circulating Tumor DNA Sequencing. J. Clin. Oncol. Off. J. Am. Soc. Clin. Oncol. 2018, 36, JCO1800328.

(C) 2020 by the authors. Licensee MDPI, Basel, Switzerland. This article is an open access article distributed under the terms and conditions of the Creative Commons Attribution (CC BY) license (http://creativecommons.org/licenses/by/4.0/). 